\title{
Carbon dioxide and methane fluxes across the sediment-water interface in different grass carp Ctenopharyngodon idella polyculture models
}

\author{
Yinghuai Xiong ${ }^{1}$, Fang Wang ${ }^{1, *}$, Xiantao Guo ${ }^{1}$, Feng Liu ${ }^{2}$, Shuanglin Dong ${ }^{1}$ \\ ${ }^{1}$ Key Laboratory of Mariculture, Ministry of Education, Ocean University of China, Qingdao 266003, PR China \\ ${ }^{2}$ Shandong Freshwater Fisheries Research Institute, Jinan 250000, PR China
}

\begin{abstract}
Benthic fluxes of carbon dioxide $\left(\mathrm{CO}_{2}\right)$ and methane $\left(\mathrm{CH}_{4}\right)$ were evaluated in grass carp Ctenopharyngodon idella (G), silver carp Hypophthalmichthys molitrix (S), and bighead carp Aristichthys nobilis (B) polyculture systems, to which topmouth culter Erythroculter ilishaeformis (T), Pacific white shrimp Litopenaeus vannamei (P), or common carp Cyprinus carpio (C) were added. These systems, GSBT, GSBP, and GSBC, respectively, were monitored over 5 mo (May to September 2014). The presence of $L$. vannamei and C. carpio increased $\mathrm{CO}_{2}$ and $\mathrm{CH}_{4}$ emissions in GSBP and GSBC, respectively. From June to August, $\mathrm{CO}_{2}$ and $\mathrm{CH}_{4}$ fluxes increased in the 3 systems, and in July and August these fluxes were significantly higher in GSBC than in GSBP and GSBT, and significantly higher in GSBP than in GSBT. The metabolisms of $L$. vannamei and $C$. carpio contributed to decrease dissolved oxygen, $\mathrm{pH}$, and oxidation-reduction levels, and the bioturbation of the upper sediment layers caused by these species increased organic matter degradation rate, resulting in a significant increase in particulate and dissolved organic carbon in the overlying water. Our results indicate that improving feeding efficiency and reducing organic carbon accumulation on the bottom of aquaculture ponds, as well as increasing dissolved oxygen and decreasing bioturbation across the sediment-water interface during farming seasons, is likely to reduce $\mathrm{CO}_{2}$ and $\mathrm{CH}_{4}$ release from aquaculture pond sediment, especially in July and August.
\end{abstract}

KEY WORDS: Carbon dioxide fluxes - Methane fluxes - Grass carp polyculture ponds . Sediment-water interface $\cdot$ Bioturbation

\section{INTRODUCTION}

Carbon dioxide $\left(\mathrm{CO}_{2}\right)$ and methane $\left(\mathrm{CH}_{4}\right)$, the major atmospheric long-lived greenhouse gases (LLGHGs), are infrared absorbers and have been implicated in global warming, due to their increasing atmospheric concentrations since the industrial revolution. Whereas $\mathrm{CO}_{2}$ concentration increased from 280.0 to $389.0 \mathrm{ppm}$ from 1800 to 2010 (Tarasova et al. 2012), $\mathrm{CH}_{4}$ increased from approximately 0.7 to $1.8 \mathrm{ppm}$ from 1999 to 2005 (Forster et al. 2007). Global warming due to increasing concentrations of LLGHGs in the atmosphere is likely to affect ecosystem structure and functioning, and many studies

${ }^{*}$ Corresponding author: wangfang249@163.com have focused on $\mathrm{CO}_{2}$ and $\mathrm{CH}_{4}$ fluxes across the water-air interface in aquatic ecosystems, including oceans, rivers, reservoirs, and lakes (Smith et al. 2000, Huttunen et al. 2002, Bange 2006, Hirota et al. 2007, Zhang et al. 2008, Tremblay \& Bastien 2009, Koné et al. 2010). Although several studies have considered $\mathrm{CO}_{2}$ and $\mathrm{CH}_{4}$ fluxes across the sedimentwater interface in these aquatic systems (Moosavi et al. 1996, Liikanen \& Martikainen 2003, Adams 2005, Huttunen et al. 2006), data on freshwater aquaculture ponds are still limited.

Globally, aquaculture provides around $47 \%$ of all fish supply destined for direct human food consumption, accounting for a growing percentage of the total

(C) The authors 2017. Open Access under Creative Commons by Attribution Licence. Use, distribution and reproduction are unrestricted. Authors and original publication must be credited. 
fish supply from approximately $13 \%$ in 1990 to $40 \%$ in 2010. About $90 \%$ of the global aquaculture production occurs in Asia, and China alone is responsible for more than $60 \%$ of that production (FAO 2013). China's total aquaculture production in 2014 reached 64.6 million metric tons (Mt), with freshwater aquaculture accounting for $45.51 \%$ of this volume (Fisheries Department of Agriculture Ministry of China 2015). Freshwater aquaculture ponds are estimated to occupy $87500 \mathrm{~km}^{2}$ worldwide, $25669 \mathrm{~km}^{2}$ (29.34\%) of which are located in China (Verdegem \& Bosma 2009). Freshwater aquaculture ponds sequester about

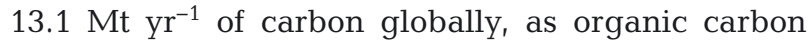
settles to the bottom of the ponds (Boyd et al. 2010, Adhikari et al. 2012). Therefore, China's freshwater aquaculture ponds play an important role in the global supply of aquatic products as well as in carbon sequestration.

The boundary between water and sediment, i.e. the sediment-water interface, shows significant variations in its physical, chemical, and biological characteristics (Schindler 1981, Nixon 1986), and plays a vital role in the circulation, transfer, and storage of materials in aquatic ecosystems (Santschi et al. 1990). Sediment is a source of LLGHGs such as $\mathrm{CH}_{4}$ and $\mathrm{CO}_{2}$ (Adams 2005, Beaulieu et al. 2009, Atkins et al. 2013), which are dissolved in the overlying water, or are emitted to the atmosphere through molecular diffusion, plant transport, or gas bubbles (Belger et al. 2011). Both $\mathrm{CH}_{4}$ and $\mathrm{CO}_{2}$ might originate from the organic carbon accumulated in freshwater pond substrates due to uneaten feed, organic fertilizers, dead plankton, and cultured species excreta (Bachoon \& Jones 1992, Liikanen et al. 2002, Algesten et al. 2005, Shalini et al. 2006, Laverman et al. 2010, Adhikari et al. 2012). However, detailed studies quantifying $\mathrm{CO}_{2}$ and $\mathrm{CH}_{4}$ fluxes across the sediment-water interface in freshwater aquaculture ponds have not been conducted so far.

Most species produced in aquaculture systems, such as carp, feed low on the food chain in their natural habitats (FAO 2013). In China, aquaculture systems are often stocked with several species of carp, including grass carp Ctenopharyngodon idella (G), silver carp Hypophthalmichthys molitrix (S), and bighead carp Aristichthys nobilis (B) (Zhang et al. 2011). Grass carp is one of the most popular freshwater aquaculture species worldwide, and accounts for about $18.31 \%$ of the total yield of freshwater aquaculture in China (Fisheries Department of Agriculture Ministry of China 2015). China's rapidly growing population and steep increase in demand for protein require the intensive utilization of in- creasingly scarce resources, and thus innovative solutions are necessary to intensify freshwater aquaculture production to keep pace with population increase. Considering ecological and economic concerns, polyculture (i.e. the simultaneous culture of several species) has been used as a means of species diversification (Soto 2009), and numerous pelagic or benthonic organisms, such as the topmouth culter Erythroculter ilishaeformis, the common carp Cyprinus carpio, and the Pacific white shrimp Litopenaeus vannamei, are generally stocked in inland ponds to take full advantage of the available space (Naylor et al. 2000, Dong 2011, Zhu et al. 2011, Han et al. 2015). Ponds stocked with these species have become important polyculture models in northern China.

From an environmental perspective, the impact of new freshwater aquaculture production technologies on the emission of greenhouse gases deserves attention. Acting as bioturbators, macrobenthos can promote the degradation rate of organic matter (OM), by modifying sediment textures and changing oxygen supply due to burrowing, feeding, respiration, and excretion (Jordan \& Valiela 1982, Jones et al. 1994, Levinton 1995, Welsh 2003, Kogure \& Wada 2005, Meysman et al. 2006, Otani et al. 2010). These processes can also promote OM mineralization, via microbial respiration, and gas emissions in the watersediment interface (Kikuchi 1986, Wheatcroft 2006). In the present study, E. ilishaeformis (T), L. vannamei $(\mathrm{P})$, and C. carpio (C) were added to C. idella polyculture ponds to create 3 different polyculture systems, in which $\mathrm{CO}_{2}$ and $\mathrm{CH}_{4}$ fluxes across the watersediment interface were evaluated. The present study aimed to test the hypothesis that stocking $C$. idella polyculture ponds with benthic species may lead to long-term increases in $\mathrm{CO}_{2}$ and $\mathrm{CH}_{4}$ fluxes across the sediment-water interface. In addition, the effects of C. carpio and L. vannamei on the $\mathrm{CO}_{2}$ and $\mathrm{CH}_{4}$ fluxes were determined and screened for differences, and the geochemical principle influencing $\mathrm{CO}_{2}$ and $\mathrm{CH}_{4}$ release was analyzed, considering several environmental parameters in the sediment-water interface.

\section{MATERIALS AND METHODS}

\section{Experimental ponds}

The present study was conducted at a freshwater fish farm in Gaoqing, Shandong Province, China $\left(37^{\circ} 04^{\prime} \mathrm{N}, 117^{\circ} 33^{\prime} \mathrm{E}\right)$, which has a typical temperate monsoonal climate, with a mean annual temperature of $13.1^{\circ} \mathrm{C}$. Nine representative Ctenopharyngodon 
idella polyculture ponds, with an area of $0.25 \mathrm{hm}^{2}$ and an average water depth of $1.8 \pm 0.5 \mathrm{~m}$, were selected and 3 polyculture systems were investigated: (1) GSBT: C. idella, Hypophthalmichthys molitrix, Aristichthys nobilis, and Erythroculter ilishaeformis; (2) GSBP: C. idella, H. molitrix, A. nobilis, and Litopenaeus vannamei; and (3) GSBC: C. idella, $H$. molitrix, A. nobilis, and Cyprinus carpio. Three replicates were established for each treatment. Pellet feed was provided every day at 07:00, 10:00, 13:00, and 16:00 $\mathrm{h}$, and pond water was not changed during the experiment. The basic details and starting conditions of the surface sediment in the 3 systems are given in Tables $1 \& 2$, respectively.

\section{Sampling}

Bottom-water and sediment samples were collected from 3 sampling sites within each pond, around the 15th day of every month, from May to September 2014. The 3 sampling sites were evenly positioned on a circle centered on the aerator. The radius of the circle was 10-11 $\mathrm{m}$ and the distance between sampling sites was $17-18 \mathrm{~m}$. In addition, the diel variation in $\mathrm{CO}_{2}$ and $\mathrm{CH}_{4}$ was examined in samples collected at $4 \mathrm{~h}$ intervals from 00:00 to $24: 00 \mathrm{~h}$, on 15 August 2014. Bottom-water samples were collected using a 2.51 polymethyl methacrylate water sampler (Yuanda Nikkor), approximately $10-20 \mathrm{~cm}$ above the sediment layers, and transported to the laboratory for incubation. Sediment samples were collected with a core sampler $(50 \mathrm{~mm}$ in diameter $\times 35 \mathrm{~cm}$ in length; Wang \& Xu 2004), and transported to the laboratory for incubation and analyses of environmental parameters, including water temperature, dissolved oxygen (DO), $\mathrm{pH}$, dissolved inorganic carbon (DIC), dissolved organic carbon (DOC), and particulate organic carbon (POC) in the overlying water, and oxidationreduction potential (Eh), OM, and total carbon (TC) in the surface sediment.
Table 1. Basic information on the 3 experimental polyculture systems. The GSBT, GSBP, and GSBC ponds were stocked with grass carp Ctenopharyngodon idella (G: 0.28 to $0.32 \mathrm{~kg}$ ind. ${ }^{-1}$ ), silver carp Hypophthalmichthys molitrix (S: 0.18 to $0.21 \mathrm{~kg}$ ind. ${ }^{-1}$ ), and bighead carp Aristichthys nobilis (B: 0.18 to $0.21 \mathrm{~kg}$ ind..$^{-1}$ ), to which topmouth culter Erythroculter ilishaeformis $(\mathrm{T})$, Pacific white shrimp Litopenaeus vannamei (P), or common carp Cyprinus carpio (C) were added, respectively. Fishes were stocked in May, shrimps at the beginning of June. Fishes and shrimps were harvested at the beginning of October. Feed input refers to the total feed input during the culture period. Means are given \pm SD

\begin{tabular}{|lccc|}
\hline Parameter & GSBT & GSBP & GSBC \\
\hline Stocking $\left(\mathrm{kg} \mathrm{m}^{-3}\right)$ & 0.57 & 0.58 & 0.57 \\
Stocking density & G:1.74; & G:1.76; & G:1.78; \\
$\quad$ ind. ${ }^{-3}$ ) & S:0.14; & S:0.15; & S:0.14; \\
& B:0.04; & B:0.04; & B:0.04; \\
& T:0.14 & P:35.51 & C:0.46 \\
Yield (all species; & 2.72 & 3.15 & 3.11 \\
$\mathrm{~kg} \mathrm{~m}^{-3}$ ) & & & \\
Feed input $\left(\mathrm{kg} \mathrm{m}^{-3}\right)$ & 3.97 & 4.14 & 4.06 \\
Transparency (m) & $0.22 \pm 0.09$ & $0.27 \pm 0.18$ & $0.20 \pm 0.07$ \\
Phosphate $\left(\mathrm{mg} \mathrm{l}^{-1}\right)$ & $0.65 \pm 0.31$ & $0.81 \pm 0.27$ & $0.93 \pm 0.18$ \\
Ammonia $\left(\mathrm{mg} \mathrm{l}^{-1}\right)$ & $1.21 \pm 0.98$ & $1.46 \pm 1.14$ & $1.72 \pm 1.25$ \\
\hline
\end{tabular}

water in each chamber was carefully replaced with bottom water using a rubber pipe, maintaining the water flow low enough to avoid any disturbance of the sediment surface. When chambers were filled with bottom water, cores were sealed with rubber stoppers. Two magnets, one placed at the upper lid of each chamber plus a central magnet (Fig. 1), allowed stirring of samples at $50 \mathrm{rpm}$ during the water-bath incubation, performed in the darkness, for $4 \mathrm{~h}$, at the in situ temperature (May, $21.33^{\circ} \mathrm{C}$; June, $28.37^{\circ} \mathrm{C}$; July, $30.60^{\circ} \mathrm{C}$; August, $32.53^{\circ} \mathrm{C}$ ind September, $24.31^{\circ} \mathrm{C}$ ). Two samples containing only bottom water were incubated in the same conditions and used as controls.

Temperature and DO concentration in the overlying water were determined using a digital DO meter (YSI 550), and $\mathrm{pH}$ was measured using an acidometer (PHS-3C; Shanghai REX Instruments). The redox potential (Eh) of surface sediment was measured

\section{Laboratory incubation and analyses of LLGHGs}

The $\mathrm{CO}_{2}$ and $\mathrm{CH}_{4}$ fluxes across the sediment-water interface were determined by ex situ incubation. All sediment samples were brought to the laboratory within $1 \mathrm{~h}$ after collection and left for $2 \mathrm{~h}$ in the incubation chambers to recover equilibrium. After equilibration, the overlying
Table 2. Starting conditions in the sediment of polyculture systems GSBT, GSBP, and GSBC (see Table 1 for abbreviations). Eh: redox potential. Means \pm SD

\begin{tabular}{|lrrr|}
\hline & \multicolumn{1}{c}{ GSBT } & \multicolumn{1}{c|}{ GSBP } & \multicolumn{1}{c|}{ GSBC } \\
\hline Eh $(\mathrm{mV})$ & $-136.17 \pm 9.93$ & $-132.67 \pm 7.97$ & $-139.83 \pm 9.02$ \\
Organic matter $(\%)$ & $3.82 \pm 0.27$ & $4.15 \pm 0.35$ & $3.95 \pm 0.32$ \\
Total carbon $\left(\mathrm{mg} \mathrm{g}^{-1}\right)$ & $24.56 \pm 0.53$ & $24.12 \pm 0.28$ & $23.62 \pm 0.53$ \\
Total nitrogen $\left(\mathrm{mg} \mathrm{g}^{-1}\right)$ & $2.48 \pm 0.17$ & $2.16 \pm 0.18$ & $2.42 \pm 0.19$ \\
\hline
\end{tabular}


with an oxidation-reduction potentiometer (AZ8551; AZ Instruments). Sediment samples were dried at $60^{\circ} \mathrm{C}$ until all water was evaporated, and then sieved through a $1 \mathrm{~mm}$ mesh. OM contents were measured as loss on ignition (LOI) after combustion at $450^{\circ} \mathrm{C}$ in a muffle furnace for at least $5 \mathrm{~h}$. DOC and DIC in the overlying water were analyzed in a total organic carbon (TOC) analyzer (multi N/C ${ }^{\circledR} 2100$; Analytik Jena), after passing through pre-combusted $\left(450^{\circ} \mathrm{C}\right.$, 2 h) Whatman GF/F-filters. Filtered POC in the overlying water and sediment TC were determined with a CHONS elemental analyzer (Vario ELIII; Elementar Analysensysteme).

Water samples $(100 \mathrm{ml})$ were taken from the sediment surface-water column within each incubation chamber, and transferred to headspace vials to determine dissolved $\mathrm{CO}_{2}$ and $\mathrm{CH}_{4}$ concentrations using gas chromatography based on gas-stripping methods (Zhang et al. 2010). Within each vial, $50 \mathrm{ml}$ of the sample were replaced with nitrogen, shaken vigorously for $5 \mathrm{~min}$, and then allowed to equilibrate for at least $2 \mathrm{~h}$. Finally, the headspace gas was analyzed with a gas chromatograph (GC-2010 Plus; Shimadzu) equipped with a TDX $(2 \mathrm{~m} \times 2 \mathrm{~mm}, 60-80$ mesh) column. The $\mathrm{CO}_{2}$ gas samples were placed into the MGS-4 gas sampler (a manual gas sampler for the GC-2010 Plus), and converted into $\mathrm{CH}_{4}$ in the MTN-1 methanizer using a nickel catalyst at $375^{\circ} \mathrm{C}$, after being separated from the TDX column at $40^{\circ} \mathrm{C}$. The concentrations of $\mathrm{CO}_{2}$ and $\mathrm{CH}_{4}$ were then deter- mined with a flame ionization detector at 220 and $90^{\circ} \mathrm{C}$, respectively. Carrier gas (nitrogen) flow rate was $22 \mathrm{ml} \mathrm{min}^{-1}$, and flame gases (hydrogen and compressed air) flow rates were set at 20 and $30 \mathrm{ml} \mathrm{min}^{-1}$, respectively. Standard gases were measured every 4 runs to determine sample concentrations and check for errors. Precisions of repeated analysis of water samples were about $5 \%$ for $\mathrm{CO}_{2}$ and $3 \%$ for $\mathrm{CH}_{4}$.

Dissolved $\mathrm{CO}_{2}$ and $\mathrm{CH}_{4}$ concentrations in water samples were calculated applying Henry's law and taking solubility dependence upon temperature into account (Lide \& Frederikse 1997). Measured $\mathrm{CO}_{2}$ and $\mathrm{CH}_{4}$ concentrations in the overlying water were compared to their theoretical concentrations in equilibrium with the atmosphere. The atmospheric concentrations used in calculations were the seasonal average air concentrations of $\mathrm{CO}_{2}$ and $\mathrm{CH}_{4}$, which were sampled with polypropylene syringes $1 \mathrm{~m}$ above the pond surface, during chamber measurements.

The $\mathrm{CO}_{2}$ and $\mathrm{CH}_{4}$ fluxes across the sedimentwater interface were calculated using Eq. (1) (Zheng et al. 2009, Zhong et al. 2015a,b):

$$
F=\frac{\Delta C \times V}{A \times t}
$$

where $F$ is the $\mathrm{CO}_{2}$ or $\mathrm{CH}_{4}$ flux $\left(\mathrm{mmol} \mathrm{m}^{-2} \mathrm{~d}^{-1}\right), \Delta C$ is the variation in $\mathrm{CO}_{2}$ or $\mathrm{CH}_{4}$ concentration measured before and after incubation, after being corrected according to atmospheric $\mathrm{CO}_{2}$ or $\mathrm{CH}_{4}$ concentration in the control incubators $\left(\mathrm{mmol} \mathrm{l}^{-1}\right), V$ is the volume

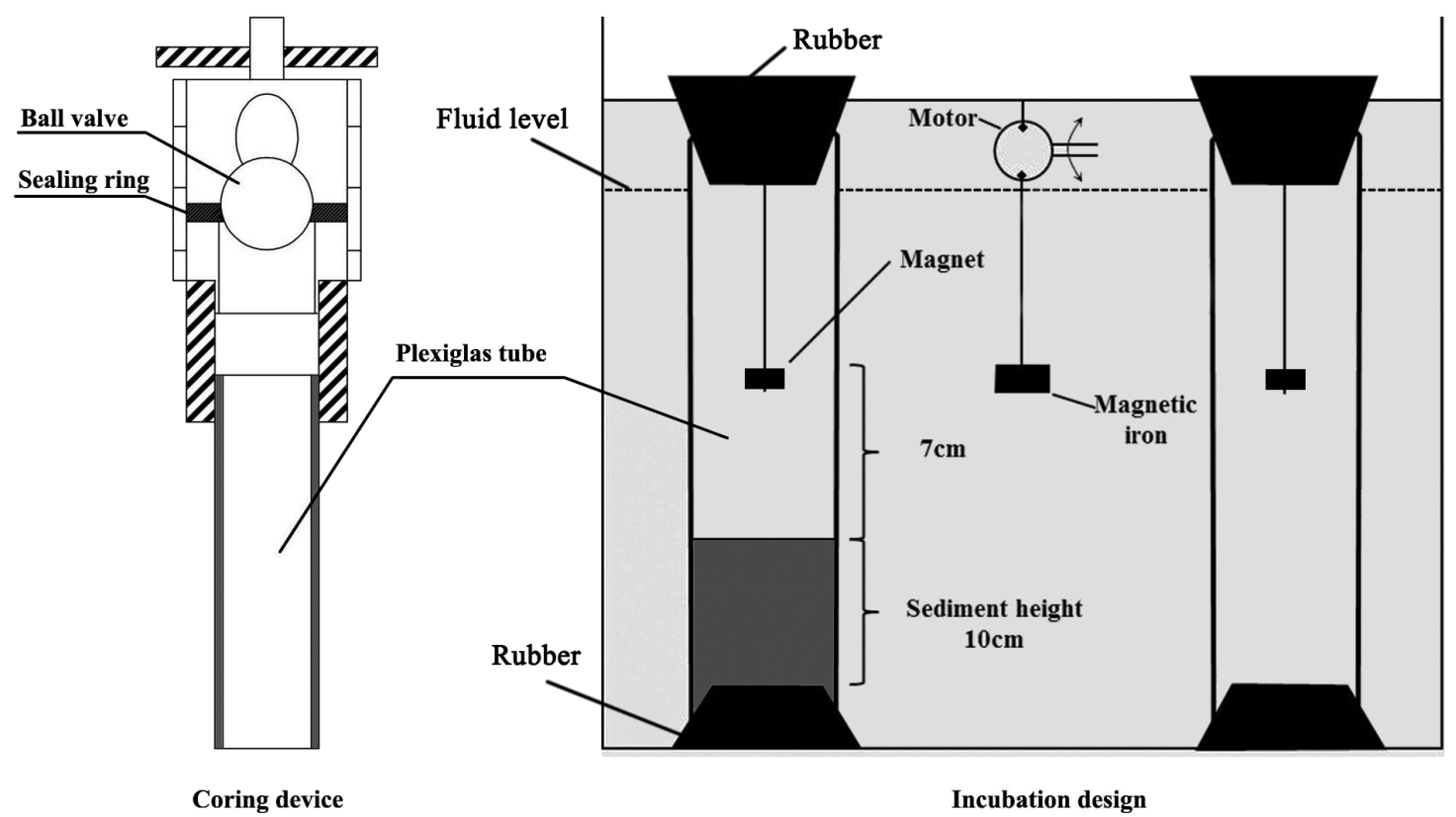

Fig. 1. Sketch of the coring device $(50 \mathrm{~mm}$ diameter $\times 35 \mathrm{~cm}$ long) used to extract sediment samples from 3 different experimental polyculture systems (see Table 1). Also shown is the general design for sediment incubation in the laboratory. The incubation and analyses are described in detail in 'Laboratory incubation and analyses of LLGHGs' 
of the incubator $\left(\mathrm{m}^{3}\right), A$ is the bottom area of the incubator $\left(\mathrm{m}^{2}\right)$, and $t$ is the incubation duration (d). Negative fluxes of $\mathrm{CO}_{2}$ or $\mathrm{CH}_{4}$ indicated sediment $\mathrm{CO}_{2}$ or $\mathrm{CH}_{4}$ absorption from the water, whereas positive fluxes indicated that $\mathrm{CO}_{2}$ or $\mathrm{CH}_{4}$ were released into the water-sediment interface.

\section{Statistical analysis}

Analyses were performed in SPSS for Windows 21.0. Means were compared using analysis of variance (ANOVA), followed by Duncan's multiple range tests for post hoc comparisons. The fluxes of $\mathrm{CO}_{2}$ and $\mathrm{CH}_{4}$ were correlated to environmental factors using Pearson's correlation method.

\section{RESULTS}

\section{Overlying water and surface sediment characteristics}

The overlying water characteristics determined for the 3 polyculture systems are shown in Fig. 2a-f. Overlying water temperature varied between 21.30 and $32.63^{\circ} \mathrm{C}$, peaking in August (Fig. 2a). Minimum DO concentrations were registered in August and maximum concentrations in May, and average values differed significantly between polyculture systems from June to September (Fig. 2b). The presence of Litopenaeus vannamei and Cyprinus carpio tended to decrease DO concentration in the overlying water. A similar trend was obtained for $\mathrm{pH}$, with GSBC presenting the lowest values and GSBT the highest
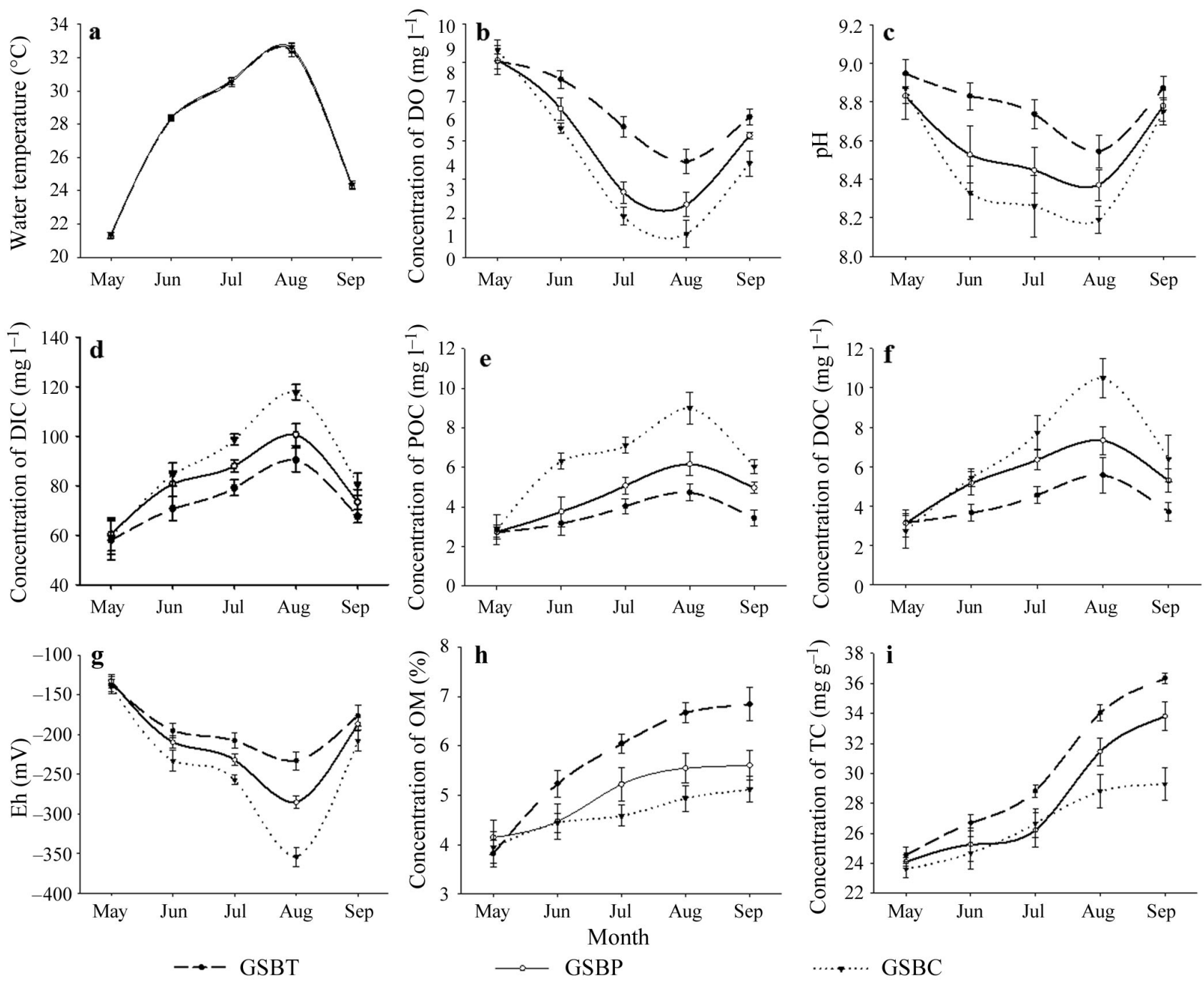

Fig. 2. Monthly variations in (a) temperature, (b) dissolved oxygen (DO), (c) pH, (d) dissolved inorganic carbon (DIC), (e) particulate organic carbon (POC), and (f) dissolved organic carbon (DOC) in the overlying water and (g) redox potential (Eh), (h) organic matter (OM), and (i) total carbon (TC) in the surface sediment of GSBT, GSBP, and GSBC experimental polyculture ponds (see Table 1 for polyculture system abbreviations) 
(Fig. 2c). The DIC concentration in the overlying water increased gradually from May to August (Fig. 2d). The highest values were observed in GSBC ponds in July and August, and were remarkably higher than that in GSBT and GSBP ponds, within the same period. Similar trends were observed for POC and DOC, whose highest values were observed in GSBC ponds and lowest in GSBT ponds (Fig. 2e,f). Therefore, the presence of $L$. vannamei and C. carpio seemed to increase DIC, DOC, and POC concentrations in the overlying water.

The surface sediment characteristics for the 3 polyculture systems are shown in Fig. $2 g-i$. The minimum Eh occurred in August and the maximum in May, and significant differences were detected among polyculture systems in July and August (Fig. 2g). The presence of $L$. vannamei and C. carpio tended to decrease Eh in the surface sediment. Both $\mathrm{OM}$ and TC accumulated in the sediments of the 3 polyculture systems throughout the experiment (Fig. 2h,i), with GSBT ponds presenting the highest $\mathrm{OM}$ and TC concentrations from June to September.

\section{Fluxes of $\mathrm{CO}_{2}$ and $\mathrm{CH}_{4}$ at the sediment-water interface}

Average $\mathrm{CO}_{2}$ fluxes (in mmol m $\mathrm{m}^{-2} \mathrm{~d}^{-1}$ ) at the sediment-water interface were 24.19 (range: 10.8637.08), 35.15 (12.25-51.95), and 43.58 (12.67-67.71) in GSBT, GSBP, and GSBC ponds, respectively (Fig. 3a). The $\mathrm{CO}_{2}$ fluxes in the 3 polyculture systems increased gradually from May to August, peaking in August. No significant differences were observed among culture systems in May ( $p$ > 0.05), but $\mathrm{CO}_{2}$ fluxes were significantly higher in GSBC than in the other 2 systems in July and August $(\mathrm{p}<0.05)$. The $\mathrm{CO}_{2}$ fluxes were significantly higher in GSBP than in GSBT ( $<0.05)$, except for May and September (Fig. 3a).

Average $\mathrm{CH}_{4}$ fluxes (in mmol m${ }^{-2} \mathrm{~d}^{-1}$ ) at the sediment-water interface were 0.58 (range: $0.27-1.37$ ) in GSBT, $1.16(0.25-2.76)$ in GSBP, and $2.26(0.37-5.29)$ in GSBC (Fig. 3b). In all culture systems, $\mathrm{CH}_{4}$ fluxes increased from May to August and decreased in September (Fig. 3b). Throughout the experiment, $\mathrm{CH}_{4}$ fluxes were consistently higher in GSBC than in GSBT and GSBP, except in May ( $p>0.05)$, and significantly higher in GSBP than in GSBT from July to September $(p<0.05$; Fig. 3b).

\section{Diel variation in $\mathrm{CO}_{2}$ and $\mathrm{CH}_{4}$ concentrations}

Within $24 \mathrm{~h}$, the $\mathrm{CO}_{2}$ concentration in the overlying water varied from 37.46 to $77.19 \mathrm{mmol} \mathrm{l}^{-1}$ in GSBT, 60.31 to $119.31 \mathrm{mmol} \mathrm{l}^{-1}$ in GSBP, and 71.34 to $112.59 \mathrm{mmol} \mathrm{l}^{-1}$ in GSBC (Fig. 4a). The $\mathrm{CO}_{2}$ concentrations increased gradually from 16:00 to $00: 00 \mathrm{~h}$, peaked at 04:00 $\mathrm{h}$, and gradually decreased thereafter. From 16:00 to 12:00 h, $\mathrm{CO}_{2}$ concentrations were significantly higher in GSBP and GSBC than in GSBT ( $\mathrm{p}<0.05)$, except at 20:00 h. At 8:00 and 12:00 h, $\mathrm{CO}_{2}$ concentrations were significantly higher in GSBC than in GSBP ( $p<0.05$; Fig. 4a).

Diel variations of the $\mathrm{CH}_{4}$ concentration in the overlying water of the 3 culture systems are shown in Fig. 4b. The $\mathrm{CH}_{4}$ concentrations (in $\mathrm{mmol} \mathrm{m}^{-2} \mathrm{~d}^{-1}$ ) ranged from 0.77 to 2.11 in GSBT, 1.44 to 3.53 in
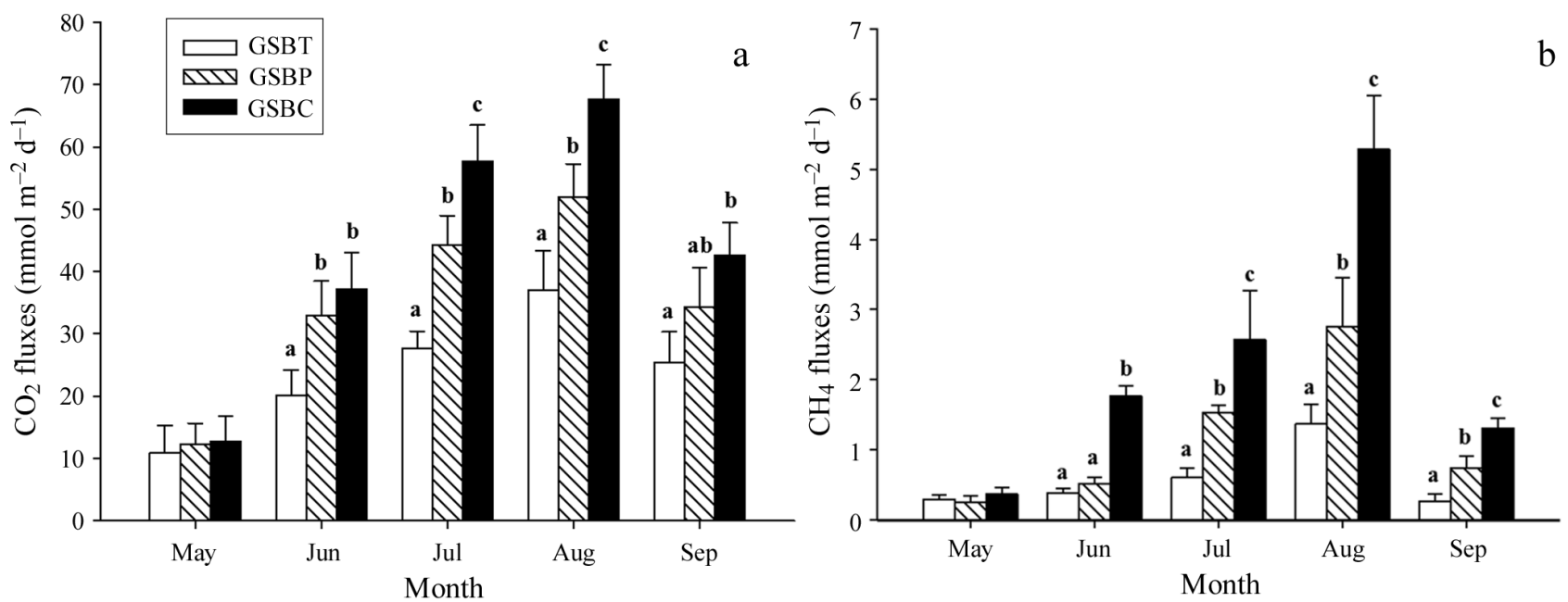

Fig. 3. (a) Carbon dioxide and (b) methane fluxes across the sediment-water interface in the 3 experimental polyculture systems (see Table 1) from May to September 2014. Bars denote standard deviation $(\mathrm{n}=3)$. Different letters indicate significant differences at $\mathrm{p}<0.05$, according to ANOVA and Duncan's multiple range tests 

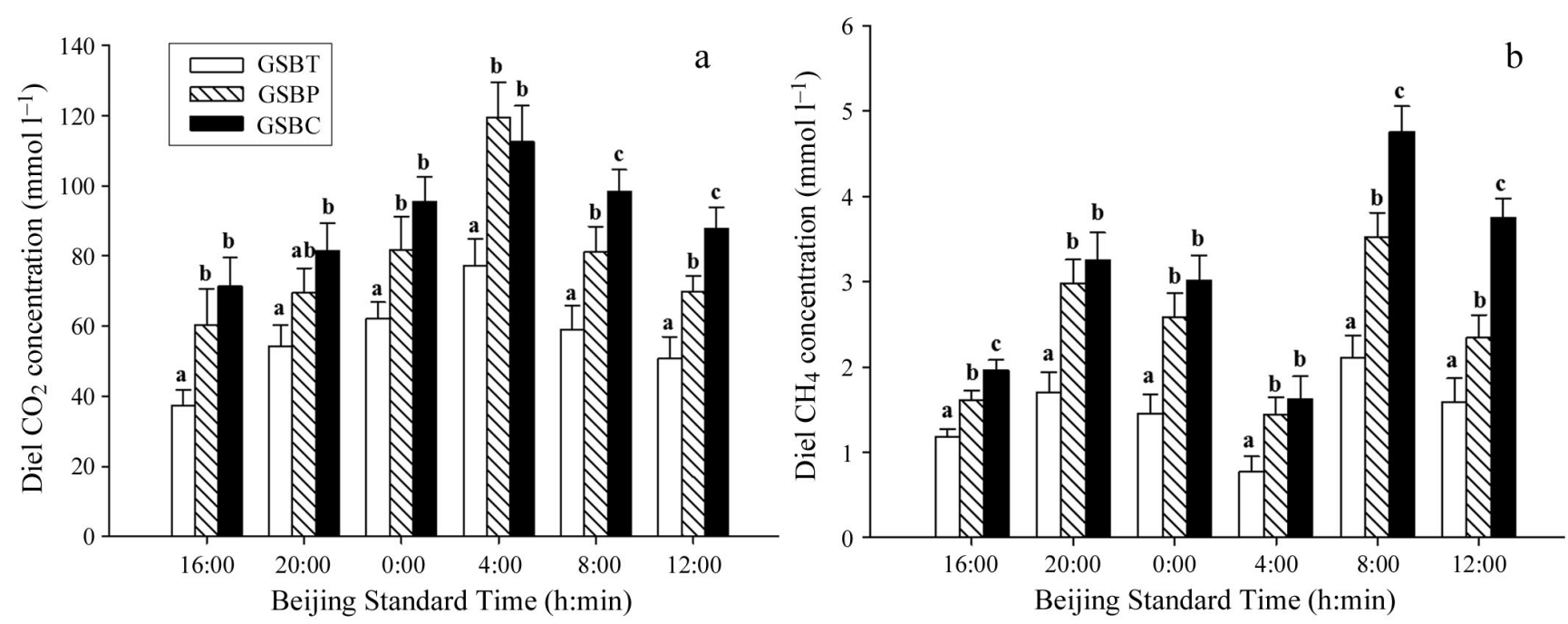

Fig. 4. Diel variation in (a) carbon dioxide and (b) methane concentrations in the overlying water of the 3 experimental polyculture systems (see Table 1) in August 2014. Bars denote standard deviation $(n=3)$. Different letters indicate significant differences at $\mathrm{p}<0.05$ by ANOVA and Duncan's multiple range tests

GSBP, and 1.62 to 4.76 in GSBC. The minimum $\mathrm{CH}_{4}$ concentrations occurred at 04:00 $\mathrm{h}$ and the maximum at 08:00 h. Over a daily cycle, $\mathrm{CH}_{4}$ concentrations were significantly lower in GSBT than in GSBP and GSBC ( < 0.05). At 08:00, 12:00, and 16:00 h, $\mathrm{CH}_{4}$ concentrations were significantly higher in GSBC than in GSBP $(p<0.05)$, with no significant differences at any other time.

\section{Correlation between $\mathrm{CO}_{2}$ and $\mathrm{CH}_{4}$ fluxes and environmental factors}

According to Pearson's correlations (Table 3), $\mathrm{CO}_{2}$ and $\mathrm{CH}_{4}$ fluxes were negatively correlated with DO concentrations and $\mathrm{pH}$ in the overlying water, and with surface sediment $\mathrm{Eh}_{\text {; }}$ positive correlations were found for temperature, DIC, POC, and DOC in the overlying water, and $\mathrm{OM}$ and TC in the surface sediment.

\section{DISCUSSION}

\section{Fluxes of $\mathrm{CO}_{2}$ and $\mathrm{CH}_{4}$ in aquaculture ponds and other aquatic ecosystems}

Carbon dioxide and $\mathrm{CH}_{4}$ fluxes across the sediment-water interface have been measured in different ecosystems, including oceans, rivers, reservoirs, and lakes (Moosavi et al. 1996, Liikanen \& Martikainen 2003, Adams 2005, Huttunen et al. 2006), but, to our knowledge, not in freshwater aquaculture systems. The range and average values of $\mathrm{CO}_{2}$ fluxes determined in the 3 Ctenopharyngodon idella polyculture systems evaluated in the present study (Table 4), were higher than those reported for lakes and reservoirs, but generally lower than those reported for drainage ditches and intertidal mudflats (Kikuchi 1986, Adams 2005, Schrier-Uij1 et al. 2011). Adams (2005) reported that $\mathrm{CO}_{2}$ fluxes

Table 3. Pearson correlation coefficients between $\mathrm{CO}_{2}$ and $\mathrm{CH}_{4}$ fluxes and factors in 3 polyculture systems (see Table 1 for abbreviations) during the farming season. T: temperature, DO: dissolved oxygen DIC: dissolved inorganic carbon, POC: particulate organic carbon, DOC: dissolved organic carbon, Eh: redox potential, OM: organic matter, TC: total carbon. ${ }^{*} \mathrm{p}<0.05 ;{ }^{* *} \mathrm{p}<0.01$

\begin{tabular}{|lcccccccccl|}
\hline \multirow{2}{*}{ System } & & $\mathrm{T}$ & $\mathrm{DO}$ & $\mathrm{pH}$ & $\mathrm{DIC}$ & $\mathrm{POC}$ & $\mathrm{DOC}$ & $\mathrm{Eh}$ & $\mathrm{OM}$ & $\mathrm{TC}$ \\
\hline $\mathrm{GSBT}$ & $\mathrm{CO}_{2}$ & $0.785^{* *}$ & $-0.845^{* *}$ & $-0.654^{* *}$ & $0.721^{* *}$ & $0.718^{* *}$ & $0.742^{* *}$ & $-0.830^{* *}$ & $0.794^{* *}$ & $0.678^{* *}$ \\
& $\mathrm{CH}_{4}$ & $0.761^{* *}$ & $-0.743^{* *}$ & $-0.805^{* *}$ & $0.769^{* *}$ & $0.776^{* *}$ & $0.758^{* *}$ & $-0.747^{* *}$ & 0.435 & 0.368 \\
$\mathrm{GSBP}$ & $\mathrm{CO}_{2}$ & $0.892^{* *}$ & $-0.906^{* *}$ & $-0.710^{* *}$ & $0.918^{* *}$ & $0.868^{* *}$ & $0.891^{* *}$ & $-0.926^{* *}$ & $0.645^{* *}$ & 0.468 \\
& $\mathrm{CH}_{4}$ & $0.799^{* *}$ & $-0.826^{* *}$ & $-0.674^{* *}$ & $0.864^{* *}$ & $0.945^{* *}$ & $0.752^{* *}$ & $-0.890^{* *}$ & $0.592^{*}$ & 0.434 \\
$\mathrm{GSBC}$ & $\mathrm{CO}_{2}$ & $0.892^{* *}$ & $-0.941^{* *}$ & $-0.795^{* *}$ & $0.930^{* *}$ & $0.939^{* *}$ & $0.898^{* *}$ & $-0.890^{* *}$ & $0.614^{* *}$ & $0.701^{* *}$ \\
& $\mathrm{CH}_{4}$ & $0.877^{* *}$ & $-0.794^{* *}$ & $-0.743^{* *}$ & $0.911^{* *}$ & $0.907^{* *}$ & $0.846^{* *}$ & $-0.934^{* *}$ & 0.429 & 0.500 \\
\hline
\end{tabular}


Table 4. Comparisons of $\mathrm{CO}_{2}$ fluxes $\left(\mathrm{mmol} \mathrm{m}^{-2} \mathrm{~d}^{-1}\right)$ across the water-sediment interface in different aquatic ecosystems $(\mathrm{n}=$ no. of ecosystems sampled)

\begin{tabular}{|lccccc|}
\hline Site & $\mathrm{n}$ & Average depth $(\mathrm{m})$ & Mean & Range & Reference \\
\hline Aquaculture ponds, China & 9 & 1.8 & 34.31 & $10.80-67.68$ & Present study \\
Oligotrophic lakes & 4 & $19-98$ & 0.34 & $-2.39-2.46$ & Adams (2005) \\
Mesotrophic lakes & 5 & $5-21.6$ & 2.60 & $1.47-3.93$ & Adams (2005) \\
Eutrophic lakes & 5 & $4-46$ & 3.80 & $0.74-8.57$ & Adams (2005) \\
Eutrophic reservoirs & 2 & 25.6 & 4.26 & $-0.06-17.70$ & Adams (2005) \\
Lobo Broa Reservoir, Brazil & 1 & 3 & 15.88 & $8.80-26.05$ & Adams (2005) \\
Drainage ditches, Netherlands & 7 & $0.25-0.90$ & 70.41 & $37.96-108.53$ & Schrier-Uijl et al. (2011) \\
Nanakita River intertidal & 1 & - & 166.00 & $64.00-291.00$ & Kikuchi (1986) \\
$\quad$ mudflats, Japan & & & & & \\
\hline
\end{tabular}

across the sediment-water interface progressively increased with increasing trophic levels in natural aquatic systems. Furthermore, a negative correlation between nutrient levels and the water depth and size of aquatic ecosystems has been reported (Odum \& Barrett 2005). Hence, regarding lakes or reservoirs, aquaculture ponds, drainage ditches, and intertidal mudflats as ecosystems with gradually increasing nutrient levels, the values found for $\mathrm{CO}_{2}$ fluxes across the sediment-water interface in the present study support the premise that in freshwater systems, these fluxes increase with increasing nutrient levels.

The range and average values of $\mathrm{CH}_{4}$ fluxes in the 3 C. idella polyculture systems examined here (Table 5) were higher than those reported for oligotrophic lakes and reservoirs, but generally lower than those observed in mesotrophic and eutrophic lakes or reservoirs and drainage ditches (Adams 2005, Schrier-Uijl et al. 2011). Although $\mathrm{CH}_{4}$ fluxes increased with increasing trophic levels in natural aquatic systems (Adams 2005), the values obtained in this study were lower than those reported for eutrophic lakes and reservoirs. This might be due to the DO (4.60-9.32 $\mathrm{mg} \mathrm{l}^{-1}$ ) produced by artificial aer- ation, which led to the rapid oxidation of dissolved $\mathrm{CH}_{4}$ in freshwater aquaculture ponds during the experiment. Accordingly, Conrad \& Rothfuss (1991) found that approximately $80 \%$ of the $\mathrm{CH}_{4}$ diffusing through the oxidized sediment-water interface was consumed by methanotrophs, which were limited by the $\mathrm{O}_{2}$ availability in methanogenic environments.

\section{Correlation between $\mathrm{CO}_{2}$ and $\mathrm{CH}_{4}$ fluxes and environmental factors}

Microbial activity is an important source of $\mathrm{CO}_{2}$ and $\mathrm{CH}_{4}$ in aquatic systems, and $\mathrm{CO}_{2}$ and $\mathrm{CH}_{4}$ fluxes can be affected by environmental factors such as water temperature, DO, pH, and Eh (Cicerone \& Shetter 1981, Crozier et al. 1995, Liikanen et al. 2002, Ding \& Cai 2003, Tan 2014). Correlation analysis showed that the $\mathrm{CO}_{2}$ and $\mathrm{CH}_{4}$ fluxes in all polyculture systems were positively correlated with water temperature (Table 3), which was consistent with previous indications that $\mathrm{CO}_{2}$ and $\mathrm{CH}_{4}$ concentrations in water increase with increasing water temperature (Moore \& Dalva 1993, Hamilton et al. 1995, den Heyer \& Kalff 1998). These positive correlations might be explained

Table 5. Comparisons of $\mathrm{CH}_{4}$ fluxes $\left(\mathrm{mmol} \mathrm{m}^{-2} \mathrm{~d}^{-1}\right)$ across the water-sediment interface in different aquatic ecosystems $(\mathrm{n}=$ no. of ecosystems sampled)

\begin{tabular}{|lccccc|}
\hline Site & $\mathrm{n}$ & Average depth $(\mathrm{m})$ & Mean & Range & Reference \\
\hline Aquaculture ponds, China & 9 & 1.8 & 1.33 & $0.25-5.29$ & Present study \\
Oligotrophic lakes & 4 & $19-98$ & 0.19 & $0.02-0.57$ & Adams (2005) \\
Oligotrophic reservoir & 1 & 40 & 0.39 & $0.38-0.39$ & Adams (2005) \\
Mesotrophic lakes & 5 & $5-21.6$ & 2.07 & $0.0-4.39$ & Adams (2005) \\
Eutrophic lakes & 5 & $4-46$ & 3.90 & $0.01-12.00$ & Adams (2005) \\
Eutrophic reservoirs & 2 & 25.6 & 5.24 & $0.20-19.27$ & Adams (2005) \\
Lobo Broa Reservoir, Brazil & 1 & 3 & 8.67 & $5.34-15.00$ & Adams (2005) \\
Drainage ditches, Netherlands & 7 & $0.25-0.90$ & 50.55 & $1.8-58.95$ & Schrier-Uijl et al. (2011) \\
\hline
\end{tabular}


by the increase in microbial activity and carbon mineralization caused by temperature increases, resulting in an oversaturation of $\mathrm{CO}_{2}$ and $\mathrm{CH}_{4}$ and their subsequent release from the sediment to the overlying water.

The high negative correlation observed between DO and Eh levels and $\mathrm{CO}_{2}$ and $\mathrm{CH}_{4}$ fluxes (Table 3) probably resulted from $\mathrm{CO}_{2}$ production during aerobic respiration and concomitant $\mathrm{O}_{2}$ consumption (Hamilton et al. 1995, Ballester \& dos Santos 2001). In addition, methanogens are obligate anaerobes, and DO content not only inhibits $\mathrm{CH}_{4}$ production, but also oxidizes the $\mathrm{CH}_{4}$ released from the sediment to the overlying water (Conrad 1996, Dernier Van der Gon \& Neue 1996, Bosse \& Frenzel 1998, Frenzel \& Karofeld 2000). Decreasing Eh levels might also have led to a boost in $\mathrm{CH}_{4}$ release in freshwater aquaculture ponds, as it was reported that a decrease in Eh from -200 to $-300 \mathrm{mV}$ induced a 10 -fold increase in $\mathrm{CH}_{4}$ production and a 17 -fold increase in its release in a rice field (Kludze et al. 1993).

The high negative correlation coefficients between $\mathrm{pH}$ and $\mathrm{CO}_{2}$ and $\mathrm{CH}_{4}$ fluxes (Table 3) supported the importance of this environmental variable pointed out in previous studies (Neal et al. 1998, Waldron et al. 2007, Crawford et al. 2013). Given that $\mathrm{CO}_{2}$ is easily dissolved in water, forming carbonic acid, a low $\mathrm{pH}$ indicates a high $\mathrm{CO}_{2}$ content in the water, and high $\mathrm{CO}_{2}$ diffusion gradients and efflux between the sediment and the overlying water. Similarly, Wallin et al. (2013) reported that $\mathrm{CO}_{2}$ partial pressure was higher at low $\mathrm{pH}$, but greatly decreased at high $\mathrm{pH}$. Thus, the correlations observed in the present study were probably due to all of the above-mentioned effects. In addition, the optimum $\mathrm{pH}$ of $\mathrm{CH}_{4}$ production was near neutrality, and a slight decrease in overlying water $\mathrm{pH}$ resulted in the enhancement of $\mathrm{CH}_{4}$ production and release (Wang et al. 1993).

In addition to water temperature, $\mathrm{DO}, \mathrm{pH}$, and $\mathrm{Eh}$, the $\mathrm{OM}$ and $\mathrm{TC}$ contents were important factors determining the $\mathrm{CO}_{2}$ and $\mathrm{CH}_{4}$ fluxes, as shown by the high positive correlation coefficients obtained between the fluxes of these gases and OM and TC (Table 3). Because carbon provides the substrate necessary for microbial $\mathrm{CO}_{2}$ and $\mathrm{CH}_{4}$ formation (Adams 2005, Beaulieu et al. 2009, Atkins et al. 2013), high positive correlations were observed between DIC, POC, and DOC and $\mathrm{CO}_{2}$ and $\mathrm{CH}_{4}$ fluxes (Table 3). Several studies revealed that the continuous enrichment of OM and TC increases DIC, POC, and DOC in aquatic systems (Li 2004, Yokoyama et al. 2006, Valdemarsen et al. 2009). Therefore, carbon concentration in the overlying water might reflect OM degradation rate across the water-sediment interface.

\section{Differences among the 3 polyculture systems}

In previous carbon flux and carbon form distribution experiments performed on grass carp polyculture systems (Xiong et al. 2015, 2016), we found that Litopenaeus vannamei and Cyprinus carpio tended to increase the transport and conversion of carbon from the sediment to the overlying water in a different pattern. In those studies, the carbon released from the sediment while bottom feeders were burrowing was found to be particularly important for the common carp. The increasing $\mathrm{CO}_{2}$ and $\mathrm{CH}_{4}$ fluxes in the sediment-water interface in GSBP and GSBC systems found in the present study corroborated the previous results, as they affected some environmental factors that are most important for bottom feeders. In addition, not finding significant increases in $\mathrm{CO}_{2}$ and $\mathrm{CH}_{4}$ fluxes in the GSBT system suggested that benthic respiration was important to release $\mathrm{CO}_{2}$ and $\mathrm{CH}_{4}$ (King et al. 1990, Jonsson et al. 2003). The higher DO concentration and Eh found in this system compared to those in GSBP and GSBC systems might have led to a faster oxidation of dissolved $\mathrm{CH}_{4}$, which is supported by the significant decrease in $\mathrm{DO}$ and $\mathrm{pH}$ in the overlying water and Eh in the surface sediment of GSBP and GSBC systems (Fig. 2b,c,g). Thus, the metabolism of $L$. vannamei and $C$. carpio might be important to decrease DO, pH, and Eh levels.

In fact, the release of $\mathrm{CO}_{2}$ and $\mathrm{CH}_{4}$ trapped in the sediment by L. vannamei and C. carpio was an important mechanism identified in the present study. Strong disturbances in the upper sediment layers by L. vannamei and C. carpio were observed during the experiment, and resulted in the significant increase of POC, DOC, and DIC in the overlying water of GSBP and GSBC systems (Fig. 2d-f). The higher water turbidity due to sediment disturbance might have reduced phytoplankton photosynthesis, leading to the low DO concentrations, $\mathrm{pH}$, and Eh observed in GSBP and GSBC systems (Fig. 2b,c,g) (Frei et al. 2007). The contents of OM and TC in the sediment (Fig. 2h,i) reflected $\mathrm{CO}_{2}$ and $\mathrm{CH}_{4}$ release across the water-sediment interface, with GSBT having the highest accumulation of OM and TC and the lowest $\mathrm{CO}_{2}$ and $\mathrm{CH}_{4}$ release. The enhanced OM degradation rate due to L. vannamei and C. carpio bioturbation was accompanied by a decrease in oxygen levels and increase in $\mathrm{CO}_{2}$ and $\mathrm{CH}_{4}$ release.

In the present study, $\mathrm{CO}_{2}$ fluxes were significantly higher in GSBC than in GSBP during July and August, and $\mathrm{CH}_{4}$ fluxes were significantly higher in GSBC than in GSBP in all months, except in May 
(Fig. 3). These relationships might be explained by differences in $L$. vannamei and C. carpio bioturbation. Some studies suggested that $L$. vannamei in a C. carpio polyculture pond might affect the transport and conversion of carbon in surface sediment, as $L$. vannamei sediment bioturbation depth was about 0 to $2 \mathrm{~cm}$ (Guo et al. 2012, Zhong et al. 2015a) while that of C. carpio was about 1 to $5 \mathrm{~cm}$ (Zhong et al. 2015b). Therefore, these species had different impacts on the $\mathrm{CO}_{2}$ and $\mathrm{CH}_{4}$ fluxes, as they affected overlying water and sediment characteristics differently.

It is also important to note the difference between diel variations in $\mathrm{CO}_{2}$ and $\mathrm{CH}_{4}$ concentrations in the overlying water of the 3 polyculture systems during August: $\mathrm{CO}_{2}$ and $\mathrm{CH}_{4}$ concentrations were significantly higher in GSBC than in GSBP at 08:00 and 12:00 $h$, but there were no significant differences from 20:00 to 04:00 h. This might be due to L. vannamei being more active during the night, whereas C. carpio were more active during the day, therefore disturbing the sediment at different times. Thus, $C$. carpio bioturbation seems to promote OM decomposition during daytime. Based on the results of the present study, we suggest that the diel variations in $\mathrm{CO}_{2}$ and $\mathrm{CH}_{4}$ concentrations are mainly affected by the behavior of benthic stocked organisms, which is also consistent with the $\mathrm{CO}_{2}$ and $\mathrm{CH}_{4}$ fluxes obtained in the 3 polyculture models examined here.

\section{CONCLUSIONS}

In summary, the results obtained here indicated that $\mathrm{CO}_{2}$ fluxes ranged from 10.86 to $67.71 \mathrm{mmol} \mathrm{m}^{-2}$ $\mathrm{d}^{-1}$, while $\mathrm{CH}_{4}$ fluxes varied from 0.25 to $5.29 \mathrm{mmol}$ $\mathrm{m}^{-2} \mathrm{~d}^{-1}$ during the culture period. These fluxes were negatively correlated with DO concentrations and $\mathrm{pH}$ in the overlying water and with surface sediment Eh, and positively correlated with temperature, DIC, $\mathrm{POC}$, and DOC in the overlying water, and OM and $\mathrm{TC}$ in the surface sediment. In addition, stocking Litopenaeus vannamei and Cyprinus carpio in polyculture models could promote the release of $\mathrm{CO}_{2}$ and $\mathrm{CH}_{4}$ from the sediment to the overlying water, and the different bioturbation depths of these species could affect biogeochemical processes.

Acknowledgements. This work was financially supported by Shandong province Natural Science Fund Project (ZR2014 CM042), Open Project of Guangxi Key Laboratory for Marine Biotechnology (GLMBT-201402), and Project of Shandong Key Research \& Development Plan No. 2016ZDJS 11A06.

\section{LITERATURE CITED}

Adams DD (2005) Diffuse flux of greenhouse gases methane and carbon dioxide-at the sediment-water interface of some lakes and reservoirs of the world. In: Tremblay A, Varfalvy L, Roehm C, Garneau M (eds) Greenhouse gas emissions-fluxes and processes. Springer, Berlin, p 129-153

Adhikari S, Lal R, Sahu BC (2012) Carbon sequestration in the bottom sediments of aquaculture ponds of Orissa, India. Ecol Eng 47:198-202

* Algesten G, Sobek S, Bergstrom AK, Jonsson A, Tranvik LJ, Jansson M (2005) Contribution of sediment respiration to summer $\mathrm{CO}_{2}$ emission from low productive boreal and subarctic lakes. Microb Ecol 50:529-535

Atkins ML, Santos IR, Ruiz-Halpern S, Maher DT (2013) Carbon dioxide dynamics driven by groundwater discharge in a coastal floodplain creek. J Hydrol (Amst) 493: 30-42

* Bachoon D, Jones RD (1992) Potential rates of methanogenesis in sawgrass marshes with peat and marl soils in the Everglades. Soil Biol Biochem 24:21-27

Ballester MVR, dos Santos JE (2001) Biogenic gases in tropical floodplain river. Braz Arch Biol Technol 44:141-147

Bange HW (2006) Nitrous oxide and methane in European coastal waters. Estuar Coast Shelf Sci 70:361-374

Beaulieu J, Arango C, Tank J (2009) The effects of season and agriculture on nitrous oxide production in headwater streams. J Environ Qual 38:637-646

* Belger L, Forsberg BR, Melack JM (2011) Carbon dioxide and methane emissions from interfluvial wetlands in the upper Negro River basin, Brazil. Biogeochemistry 105: 171-183

* Bosse U, Frenzel P (1998) Methane emissions from rice microcosms: the balance of production, accumulation and oxidation. Biogeochemistry 41:199-214

*Boyd CE, Wood CW, Chaney PL, Queiroz JF (2010) Role of aquaculture pond sediments in sequestration of annual global carbon emissions. Environ Pollut 158:2537-2540

* Cicerone RJ, Shetter JD (1981) Sources of atmospheric methane: measurements in rice paddies and a discussion. J Geophys Res 86:7203-7209

Conrad R (1996) Soil microorganisms as controllers of atmospheric trace gases $\left(\mathrm{H}_{2}, \mathrm{CO}, \mathrm{CH}_{4}, \mathrm{OCS}, \mathrm{N}_{2} \mathrm{O}\right.$, and NO). Microbiol Rev 60:609-640

Conrad R, Rothfuss F (1991) Methane oxidation in the soil surface layer of a flooded rice field and the effect of ammonium. Biol Fertil Soils 12:28-32

Crawford JT, Striegl RG, Wickland KP, Dornblaser MM, Stanley EH (2013) Emissions of carbon dioxide and methane from a headwater stream network of interior Alaska. J Geophys Res Biogeosci 118:482-494

* Crozier CR, Devai I, DeLaune R (1995) Methane and reduced sulfur gas production by fresh and dried wetland soils. Soil Sci Soc Am J 59:277-284

den Heyer C, Kalff J (1998) Organic matter mineralization rates in sediments: a within-and among-lake study. Limnol Oceanogr 43:695-705

* Dernier Van der Gon H, Neue HU (1996) Oxidation of methane in the rhizosphere of rice plants. Biol Fertil Soils 22:359-366

Ding WX, Cai ZC (2003) Effect of nitrogen fertilizers on methane oxidation in soils by methanotrophs. Chin J Eco Agric 11:50-53 (in Chinese with English abstract)

* Dong SL (2011) History, principles, and classification of 
integrated aquaculture in China. J Fish Sci China 18: 1202-1209 (in Chinese with English abstract)

FAO (Food and Agriculture Organization of the United Nations) (2013) FAO statistics. Global statistical collections/global aquaculture production. www.fao.org/fishery/ statistics/en

Fisheries Department of Agriculture Ministry of China (2015) China Fisheries Statistical Yearbook. China Agriculture Press, Beijing (in Chinese)

Forster P, Ramaswamy V, Artaxo P, Berntsen T and others (2007) Changes in atmospheric constituents and in radiative forcing. In: Solomon S, Qin D, Manning M, Chen Z and others (eds) Climate change 2007. The physical science basis. Contribution of Working Group I to the Fourth Assessment Report of the Intergovernmental Panel on Climate Change. Cambridge University Press, Cambridge, p 129-234

Frei M, Razzak M, Hossain M, Oehme M, Dewan S, Becker K (2007) Methane emissions and related physicochemical soil and water parameters in rice-fish systems in Bangladesh. Agric Ecosyst Environ 120:391-398

Frenzel P, Karofeld E (2000) $\mathrm{CH}_{4}$ emission from a hollowridge complex in a raised bog: the role of $\mathrm{CH}_{4}$ production and oxidation. Biogeochemistry 51:91-112

Guo YJ, Wang F, Liu HC, Zhang ZD, Dong SL, Gao QF, Zhang MZ (2012) Study on nutrients in sediment interstitial water and overlying water in different grass carp polyculture enclosures. Period Ocean Univ China 42: 82-89 (in Chinese with English abstract)

Hamilton S, Sippel S, Melack J (1995) Oxygen depletion and carbon dioxide and methane production in waters of the Pantanal wetland of Brazil. Biogeochemistry 30:115-141

Han ZP, Zhu WF, Gong XX, Zhou HQ, He Q, Xu Y (2015) Study on aquaculture technology in crab (Eriocheir japonica) and topmouth culter (Erythroculter ilishaeformis) polyculture model. J Anhui Agric Sci 43:113-115 (in Chinese)

Hirota M, Senga Y, Seike Y, Nohara S, Kunii H (2007) Fluxes of carbon dioxide, methane and nitrous oxide in two contrastive fringing zones of coastal lagoon, Lake Nakaumi, Japan. Chemosphere 68:597-603

*Huttunen JT, Väisänen TS, Hellsten SK, Heikkinen M and others (2002) Fluxes of $\mathrm{CH}_{4}, \mathrm{CO}_{2}$, and $\mathrm{N}_{2} \mathrm{O}$ in hydroelectric reservoirs Lokka and Porttipahta in the northern boreal zone in Finland. Global Biogeochem Cycles 16: 3-1-3-17

Huttunen JT, Väisänen TS, Hellsten SK, Martikainen PJ (2006) Methane fluxes at the sediment-water interface in some boreal lakes and reservoirs. Boreal Environ Res 11:27-34

Jones CG, Lawton JH, Shachak M (1994) Organisms as ecosystem engineers. Oikos 69:373-386

Jonsson A, Karlsson J, Jansson M (2003) Sources of carbon dioxide supersaturation in clearwater and humic lakes in northern Sweden. Ecosystems 6:224-235

Jordan TE, Valiela I (1982) A nitrogen budget of the ribbed mussel, Geukensia demissa, and its significance in nitrogen flow in a New England salt marsh. Limnol Oceanogr 27:75-90

Kikuchi E (1986) Contribution of the polychaete, Neanthes japonica (Izuka), to the oxygen uptake and carbon dioxide production of an intertidal mud-flat of the Nanakita River estuary, Japan. J Exp Mar Biol Ecol 97:81-93

King GM, Roslev P, Skovgaard H (1990) Distribution and rate of methane oxidation in sediments of the Florida everglades. Appl Environ Microbiol 56:2902-2911

*Kludze H, DeLaune R, Patrick W (1993) Aerenchyma formation and methane and oxygen exchange in rice. Soil Sci Soc Am J 57:386-391

Kogure K, Wada M (2005) Impacts of macrobenthic bioturbation in marine sediment on bacterial metabolic activity. Microbes Environ 20:191-199

Koné YJM, Abril G, Delille B, Borges AV (2010) Seasonal variability of methane in the rivers and lagoons of Ivory Coast (West Africa). Biogeochemistry 100:21-37

Kaverman AM, Garnier JA, Mounier EM, Roose-Amsaleg CL (2010) Nitrous oxide production kinetics during nitrate reduction in river sediments. Water Res 44: 1753-1764

Levinton J (1995) Bioturbators as ecosystem engineers: control of the sediment fabric, inter-individual interactions, and material fluxes. In: Jones CG, Lawton JH (eds) Linking species \& ecosystems. Springer, Berlin, p 29-36

Li XG (2004) Studies on inorganic carbon in offshore environments. $\mathrm{PhD}$ dissertation, Chinese Academy of Sciences, Beijing (in Chinese with English abstract)

Lide DR, Frederikse HPR (1997) Handbook of chemistry and physics, 78th edn. CRC Press, Boca Raton, FL

* Liikanen A, Martikainen PJ (2003) Effect of ammonium and oxygen on methane and nitrous oxide fluxes across sediment-water interface in a eutrophic lake. Chemosphere 52:1287-1293

ㄴiikanen A, Murtoniemi T, Tanskanen H, Väisänen T, Martikainen PJ (2002) Effects of temperature and oxygen availability on greenhouse gas and nutrient dynamics in sediment of a eutrophic mid-boreal lake. Biogeochemistry 59:269-286

Meysman FJ, Middelburg JJ, Heip CH (2006) Bioturbation: a fresh look at Darwin's last idea. Trends Ecol Evol 21: 688-695

Moore T, Dalva M (1993) The influence of temperature and water table position on carbon dioxide and methane emissions from laboratory columns of peatland soils. J Soil Sci 44:651-664

Moosavi SC, Crill PM, Pullman ER, Funk DW, Peterson KM (1996) Controls on $\mathrm{CH}_{4}$ flux from an Alaskan boreal wetland. Global Biogeochem Cycles 10:287-296

Naylor RL, Goldburg RJ, Primavera JH, Kautsky N and others (2000) Effect of aquaculture on world fish supplies. Nature 405:1017-1024

Neal C, House WA, Jarvie HP, Eatherall A (1998) The significance of dissolved carbon dioxide in major lowland rivers entering the North Sea. Sci Total Environ 210-211: 187-203

Nixon S (1986) Nutrient dynamics and the productivity of marine coastal waters. In: Halway RD, Clayton B, Behbehani M (eds) Coastal eutrophication. The Alden Press, Oxford, p 97-115

Odum E, Barrett G (2005) Fundamentals of ecology, 5th edn. Thomson Learning TM, Belmont, MA

Otani S, Kozuki Y, Yamanaka R, Sasaoka H and others (2010) The role of crabs (Macrophthalmus japonicus) burrows on organic carbon cycle in estuarine tidal flat, Japan. Estuar Coast Shelf Sci 86:434-440

Santschi P, Höhener P, Benoit G, Buchholtz-ten Brink M (1990) Chemical processes at the sediment-water interface. Mar Chem 30:269-315

Schindler PW (1981) Surface complexes at oxide-water interfaces. In: Anderson MA, Rubin AJ (eds) Adsorption 
of inorganics at solid-liquid interfaces. Ann Arbor Science, Ann Arbor, MI, p 1-49

Schrier-Uijl AP, Veraart AJ, Leffelaar PA, Berendse F, Veenendaal EM (2011) Release of $\mathrm{CO}_{2}$ and $\mathrm{CH}_{4}$ from lakes and drainage ditches in temperate wetlands. Biogeochemistry 102:265-279

Shalini A, Ramesh R, Purvaja R, Barnes J (2006) Spatial and temporal distribution of methane in an extensive shallow estuary, south India. J Earth Syst Sci 115:451-460

Smith LK, Lewis WM Jr, Chanton JP, Cronin G, Hamilton SK (2000) Methane emissions from the Orinoco River floodplain, Venezuela. Biogeochemistry 51:113-140

Soto D (2009) Integrated mariculture: a global review. FAO Fish Aquacult Tech Pap 529. Food and Agriculture Organization of the United Nations, Rome

Tan YJ (2014) The Greenhouse gases emission and production mechanism from river sediment in Shanghai. MSc thesis, East China Normal University, Shanghai (in Chinese with English abstract)

Tarasova O, Koide H, Dlugokencky E, Montzka SA, Butler $\mathrm{JH}$ (2011) The state of greenhouse gases in the atmosphere using global observations through 2010. WMO GHG Bull 8:11012. www.wmo.int/pages/prog/arep/ gaw/ghg/documents/GHGbulletin_7_en.pdf

Tremblay A, Bastien J (2009) Greenhouse gases fluxes from a new reservoir and natural water bodies in Québec, Canada. Verh Int Verein Limnol 30:866-869

*Valdemarsen T, Kristensen E, Holmer M (2009) Metabolic threshold and sulfide-buffering in diffusion controlled marine sediments impacted by continuous organic enrichment. Biogeochemistry 95:335-353

Verdegem M, Bosma R (2009) Water withdrawal for brackish and inland aquaculture, and options to produce more fish in ponds with present water use. Water Policy 11: $52-68$

Waldron S, Scott EM, Soulsby C (2007) Stable isotope analysis reveals lower-order river dissolved inorganic carbon pools are highly dynamic. Environ Sci Technol 41: 6156-6162

Wallin MB, Grabs T, Buffam I, Laudon $\mathrm{H}$, Ågren A, Öquist MG, Bishop K (2013) Evasion of $\mathrm{CO}_{2}$ from streams-the dominant component of the carbon export through the aquatic conduit in a boreal landscape. Glob Change Biol 19:785-797

Wang Z, Delaune R, Patrick W, Masscheleyn P (1993) Soil redox and $\mathrm{pH}$ effects on methane production in a flooded rice soil. Soil Sci Soc Am J 57:382-385

Welsh DT (2003) It's a dirty job but someone has to do it: the role of marine benthic macrofauna in organic matter

Editorial responsibility: Marianne Holmer,

Odense, Denmark turnover and nutrient recycling to the water column. Chem Ecol 19:321-342

*Wheatcroft RA (2006) Time-series measurements of macrobenthos abundance and sediment bioturbation intensity on a flood-dominated shelf. Prog Oceanogr 71:88-122

Xiong Y, Wang F, Chen Y, Dong S, Liu F (2015) Carbon fluxes across sediment-water interface in different grass carp poly-culture models. J Fish China 39:1005-1014 (in Chinese with English abstract)

Xiong Y, Wang F, Chen Y, Dong S, Liu F (2016) Study on distribution of different carbon forms in overlying water and sediment interstitial water in different grass carp polyculture models. Period Ocean Univ China 46:22-30 (in Chinese with English abstract)

* Yokoyama H, Abo K, Ishihi Y (2006) Quantifying aquaculture derived organic matter in the sediment in and around a coastal fish farm using stable carbon and nitrogen isotope ratios. Aquaculture 254:411-425

Khang G, Zhang J, Ren J, Li J, Liu S (2008) Distributions and sea-to-air fluxes of methane and nitrous oxide in the North East China Sea in summer. Mar Chem 110:42-55

* Zhang GL, Zhang J, Liu SM, Ren JL, Zhao YC (2010) Nitrous oxide in the Changjiang (Yangtze River) Estuary and its adjacent marine area: riverine input, sediment release and atmospheric fluxes. Biogeosciences 7:3505-3516

Zhang ZD, Wang F, Dong SL, Gao QF, Zhang MZ, Song Q, Zhang JD (2011) A preliminary study on structural optimization in polycultural systems of Ctenopharyngodon idellus with Hypophthalmichthys molitrix and Litopenaeus vannamei. Period Ocean Univ China 41:60-66 (in Chinese with English abstract)

Zheng Z, Dong S, Tian X, Wang F, Gao Q, Bai P (2009) Sediment water fluxes of nutrients and dissolved organic carbon in extensive sea cucumber culture ponds. Clean-Soil Air Water 37:218-224

K Zhong D, Wang F, Dong S, Li L (2015a) Impact of Litopenaeus vannamei bioturbation on nitrogen dynamics and benthic fluxes at the sediment-water interface in pond aquaculture. Aquacult Int 23:967-980

Zhong D, Wang F, Dong S, Khairnar SO (2015b) Benthic nutrient fluxes influenced by the common carp Cyprinus carpio in pond polyculture with special reference to nitrification, denitrification and nitrate ammonification. Indian J Fish 62:50-57

Zhu FJ, Zhu CB, Qi ZX, Zhang HH (2011) Comparison of production effect and dynamic water quality among Litopenaeus vannamei-Ctenopharyngodon idellus polyculture and shrimp monoculture system. Guangdong Agric Sci 38:147-152 (in Chinese with English abstract)

Submitted: July 26, 2016; Accepted: December 6, 2016 Proofs received from author(s): January 26, 2017 